\title{
PERBEDAAN PENENTUAN AWAL BULAN KAMARIAH DALAM PENGHITUNGAN MASA IDDAH BAGI PEREMPUAN PERSPEKTIF FIKIH
}

\author{
Muhammad Alamul Huda \\ Mahasiswa Pasca Sarjana Hukum Keluarga Islam IAIN Kudus \\ Email:alamoel23@gmail.com
}

\begin{abstract}
Women who have just been separated from marriage, either by divorce or by the death of their husband, must go through the iddah period. One of the calculations for the iddah period is the number of months. However, sometimes there are differences in the calculation of the number of months so that it has implications for time uncertainty about whether or not the period ends iddah. This study aims to explain the differences in determining the beginning of the lunar month and its implications for calculating the iddah period for women, and iddah from a figh perspective. This study uses a literature study research method. The data source used is secondary data, while the data analysis uses qualitative descriptive. The results showed that the difference in determining the beginning of the lunar month was due to the different methods used among Muslims, namely ruqyah and reckoning. The implications for determining the beginning of the month affect the calculation of the iddah period for women, especially regarding rights and obligations. Iddah itself is nothing but a waiting period for a woman to know that the uterus or womb is clean from pregnancy or for purposes ta'abbudi.
\end{abstract}

Keywords: Kamariah Month, Iddah, Women, Jurisprudence

\begin{abstract}
Abstrak
Perempuan yang baru terlepas dari ikatan pernikahan baik secara perceraian maupun ditinggal wafat suaminya harus melalui masa iddah. Salah satu penghitungan masa iddah adalah dengan jumlah bilangan bulan. Namun demikian terkadang terdapat perbedaaan penghitungan bilangan bulan sehingga berimplikasi terhadap ketidakpastian waktu tentang berakhir tidaknya masa iddah. Penelitian ini bertujuan untuk menjelaskan perbedaan penentuan awal bulan Kamariah dan implikasinya terhadap pehitungan masa iddah bagi perempuan, dan iddah perspektif Fikih. Penelitian ini menggunakan metode penelitian studi kepustakaan. Sumber data yang digunakan berupa data sekunder, sedangkan analisis data menggunakan diskriptif kualitatif. Hasil penelitian menunjukkan bahwa terjadinya perbedaan dalam penentuan awal bulan Kamariah dikarenakan metode yang digunakan dikalangan umat Islam masing-masing berbeda yakni rukyah dan hisab. Implikasi terhadap penentuan awal bulan tersebut berpengaruh terhadap penghitungan masa iddah bagi perempuan terutama terkait hak dan kewajiban. Iddah sendiri tidak lain merupakan masa tunggu bagi seorang perempuan untuk mengetahui bersihnya rahmi atau rahim dari kehamilan atau untuk tujuan $t^{\prime} a b b u d i$.
\end{abstract}

Kata Kunci: Bulan Kamariah, iddah, Perempuan, Fikih 


\section{PENDAHULUAN}

Perbedaan penentuan awal bulan kamariah masih menjadi isu hangat diantara para ahli falak. Ada dua metode berbeda yang digunakan oleh masing-masing kelompok yakni metode hisab dan metode rukyat. Jika salah menyikapi berbedaan ini dapat memunculkan kebingungan, bahkan jika salah mengambil sikap maka dapat menimbulkan perpecahan, perselisihan, dan pertentangan, bahkan permusuhan di kalangan umat Muslim. Tentunya kesalahan dalam menyikapi perbedaan seperti ini dapat berdampak buruk bagi ukhuwah dan persatuan umat Islam. Padahal kedua metode ini tentu memiliki landasan hukum yang jelas yang bersumber dari ajaran Hukum Islam. (Dirjen BIPH, 2004:1).

Penghitungan Bulan Kamariah biasa dijadikan pedoman dalam memulai kegiatan keagamaan. Salah satu kegiatan keagamaan yang bergantunng pada penentuan awal bulan adalah pelaksanaan puasa di bulan ramadhan dan perayaan idul fitri sekaligus mengakhiri bulan ramadhan di bulan syawal (Direktorat Jenderal Bimbingan Masyarakat Islam Kementrian Agama RI, 2010). Selain itu terdapat suatu ibadah yang secara khusus berpengaruh bagi perempuan yang terlepas dari ikatan pernikahan, yaitu tentang ketentuan perhitungan masa iddah (Et, 2006: 215).

Terlepasnya suatu ikatan pernikahan memberikan konsekuensi iddah yang harus dijalani sebagai masa tunggu oleh seorang perempuan. Masa "iddah dimaksudkan dalam rangka untuk mengetahui perempuan tersebut dalam keadaan hamil atau tidak, dan juga sebagai masa intropeksi dan berpikir ulang bagi suami istri untuk memutuskan arah kelanjutan status pernikahan mereka. Penentuan masa iddah dapat didasarkan pada masa haid, suci, jumlah bilangan Bulan, atau ditentukan dengan proses melahirkan (Nasution, 1999: 144).

Salah satu yang mempengaruhi masa iddah yakni penentuan awal Bulan kamariah. Penggunaan dua metode berbeda yang digunakan yakni metode hisab dan metode rukyat dalam penentuan awal Bulan kamariah berpengaruh pada ketidakpastian waktu tentang berakhir tidaknya masa iddah. Pengaruh tersebut terkait tentang tentang konsekuensi hak dan kewajiban perempuan yang akan dilakukannya dari kaca mata Fikih.

Sudah banyak penelitian maupun artikel yang membahas terkait dengan tema yang sama dengan yang penulis teliti seperti penelitian berjudul "Fiqih Hisab Rukyah di Indonesia (Telaah Sistem Penetapan Awal Bulan Qamariyyah)" yang disusun oleh Jaenal Arifin. Hasil penelitian meunjukkan bahwa metode hisab dan rukyat merupakan dua hal yang tidak dapat dipisahkan dalam penentuan awal bulan kamariah. Dalam penentuan awal bulan harus berpegang kepada hisab rukyah karena metode ini adalah metode yang ada sejak zaman rasulullah. Kedua metode tersebut keberadaannya saling melengkapi yang di 
dukung oleh akurasi data. Teori rukyah berfungsi menguji kebenaran hisab dan berguna untuk melakukan koreksi (Arifin, 2014).

Penelitian lain juga pernah dilakukan oleh Jamhuri dan Izzudin Juliara dengan judul Penggabungan Iddah Wanita Hamil dan Kematian Suami (Analisis Terhadap Pendapat Mazhab Syafi'i). terdapat dua kelompok besar, yaitu pendapat yang menyatakan iddah wanita dari dua masa keadaan tersebut diambil iddah yang terpanjang. Pendapat ini dipegang oleh sahabat Nabi dan beberapa ulama lainnya, seperti Ibnu Abbas dan Ali bin Abi Thalib, yang diikuti oleh ulama-ulama Syieah. Sedangkan pendapat lainnya yaitu dengan berpegang pada iddah sampai melahirkan anak, dimana pendapat ini dipegang oleh jumhur ulama, termasuk Imam Syafiei. Pelaksanaannya merupakan suatu ibadah sekaligus sebagai kewajiban atas wanita Secara umum penulis lebih cenderung mengatakan bahwa iddah wanita pada posisi itu adalah sampai melahirkan anak. Meskipun suami meninggal telah lama sebelum kelahiran anak, atau sesaat setelah kematian suami (Jamhuri \& Juliara, 2017). Sedangkan penelitian yang dilakukan oleh Husnul Khitam berjudul Nafkah dan Iddah: Perspektif Hukum Islam. Pada pokonya penelitian tersebut menunjukkan bahwa seorang suami wajib untuk memberi nafkah istrinya selama istri tidak nusyuz. Bahkan ketika terjadi perceraian, dalam talak raj'i dan ketika istri dalam keadaan hamil, suami masih mempunyai kewajiban untuk memberi nafkah istrinya(Khitam, 2020). Secara umum ketiga penelitian memiliki kesamaan yakni sama-sama membahas tentang iddah tetapi terdapat perbedaan yaitu penelitian ini lebih menfokuskan pada penentuan awal bulan kamariah dalam menghitung masa iddah bagi perempuan. Oleh karena itu, penelitian ini bertujuan untuk mendiskripsikan dan menjelaskan penentuan awal bulan kamariah dalam penghitungan masa iddah bagi perempuan perspektif Fikih.

\section{METODE PENELITIAN}

Penelitian yang dilakukan oleh penulis merupakan penelitian kepustakaan dengan menggunakan pendekatan kualitatif. Teknik pengumpulan data menggunakan studi kepustakan (library research) yaitu mengkaji, menelaah dan mempelajari bahan-bahan hukum yang bersumber dari peraturan perundang-undangan, buku-buku Fikih, dokumen resmi, publikasi yang ada kaitannya dengan penelitian ini.

Studi Kepustakaan dilakukan dengan cara mengumpulkan dan mendokumentasikan data-data yang bersumber dari data sekunder. analisis data mengunakan metode berpikir induktif, yaitu kesimpulan dimulai dari pernyataan atau fakta-fakta umum menuju bersifat khusus sehingga didapat suatu gambaran yang jelas tentang masalah atau suatu keadaan yang diteliti berkaitan dengan perbedaan dalam penentuan awal bulan Kamariah terkait penghitungan masa iddah bagi perempuan. 


\section{PEMBAHASAN}

\section{Perbedaan Penentuan Awal Bulan Kamariah}

Terdapat dua kelompok umat Islam yang berbeda dalam menentukan awal bulan Kamariah. Di Indonesia, dalam penentuan awal bulan Kamariah terdapat kelompok masyarakat yang berpedoman dengan rukyat dan kelompok yang berpedoman dengan hisab. Kedua metode tersebut secara mendasar tentu sangat berbeda dan sangat untuk disatukan. Kelompok dengan metode rukyah maupun hisab mempunyai alasan yang bersumber dari Al-Qur'an maupun dari Hadis. Dalam kelompok hisab sediri terdapat hisab urfi (non astronomis) dan hisab haqīqī. Selain itu sebenarnya ada kelompok yang berusaha menjadi jembatan dari perbedaan dasar tersebut yakni mazhab imkan rukyat. mazhab ini berupaya memadukan antara mazhab dengan metode hisab dan rukyat, yaitu dengan berupaya bagaimana hasil hisabnya dapat sesuai dengan rukyat dan rukyat sesuai dengan hisabnya tetapi kencenderungannya metode yang digunakan adalah dengan melihat objek sasaran berupa hilal (Izzudin, 2007: 82). Berikut perbandingan perbedaan metode rukyat dan hisab :

1. Pendapat madzhab rukyat

Dasar Argumen yang dibangun oleh madzhab rukyat dalam penetapan awal bulan Kamariah salah satunya bersumber dari hadis Nabi SAW berikut ini:

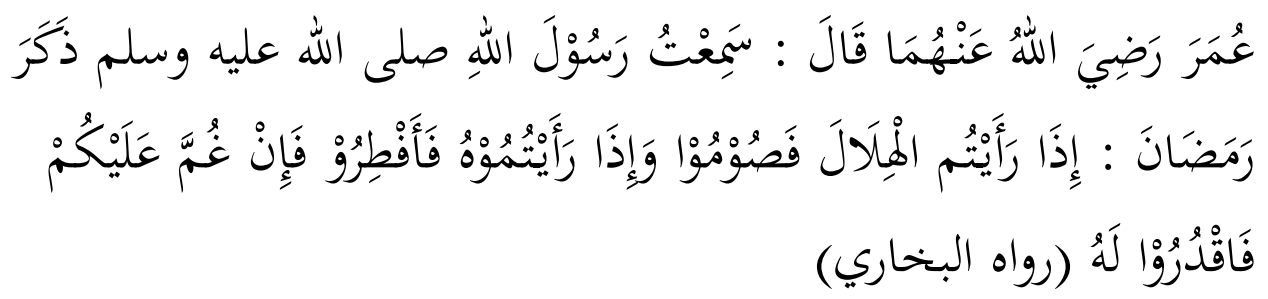

Artinya : Abdullah bin Maslamah menceritakan kepadaku, Malik bercerita kepadaku, keterangan dari Nafi' dari Abdullah bin Umar RA berkata, saya mendengar Rasulullah SAW memerbicarakan mengenai ramadhan kemudian beliau bersabda, apabila kalian melihatnya (Bulan) maka berpuasalah dan apabila kalian melihatnya (Bulan) maka berbukalah. dan jika (Bulan) tertutup (awan) bagimu, maka kira-kirakanlah. (HR. Bukhori) (Al-Hajjaj, n.d.:124).

Kelompok Madzhab rukyat adalah madzhab yang berpandangan bahwa dalam penentuan awal bulan Kamariah harus dilakukan dengan cara melihat hilal secara jelas. Biasanya awal bulan bentuk cahaya bulan terlihat seperti bulan sabit. Madzhab rukyat menafsirkan dalam dalil-dalil hadits-hadits yang berkaitan hisab rukyat bersifat ta'abbudi 
ghair ma'qul al-ma'na, artinya ketentuan penetapan awal bulan kamariah berdasarkan Hadis tersebut tidak dapat dirasionalkan pengertiannya, sehingga tidak dapat diperluas dan tidak dapat dikembangkan.

Oleh sebab itu, untuk menentukan awal Bulan Kamariah adalah dengan memastikan terlebih dahulu bahwa hilal dengan bentuk bulan sabit muda terlihat secara jelas oleh mata. Untuk melihat hilal biasanya dilakukan pada saat memasuki hari ke 29 setelah terjadi konjungsi (ijtimak) di langit (ufuk) sebelah barat sesaat pasca terbenamnya matahari.Dengan cara yang demikian maka dapat ditentukan awal bulan Kamariah berdasar terlihat tidaknya bulan sabit. (Izzudin, 2007: 46).

Madzhab rukyat meyakini bahwa awal bulan Kamariah harus dipastikan berdasarkan pada posisi bulan pasca tenggelamnya matahari dengan memakai ukuran satuan derajat. Dapat dikatakan hilal dapat dirukyat jika ketinggian bulan sabit minimal $2^{\circ}$ di atas ufuk pasca matahari. Hal itu memberi petunjuk bahwa telah esoknya berganti bulan. Sebaliknya, jika tidak terlihat bulan maka esok hari penghitumgamya digenapkan menjadi hari ke tiga puluh dari penghitungan bulan yang sedang berlangsung. Di Indonesia, penetapan awal bulan menggunakan rukyat dalam menentukan awal bukan kamariah salah satunya digunakan oleh Nahdlatul Ulama.

2. Pendapat madzhab hisab

Kelompok Madzhab dengan menggunakan hisab adalah madzhab yang berpandangan bahwa dalam penentuan awal bulan Kamariah harus didasarkan pada peredaran Bulan dan Bumi mengitari matahari. Jadi tidak harus benar-benar melihat secara jelas hilal seperti yang dilakukan oleh kelompok Madzhab rukyat. Kelompok ini menafsirkan lafal rukyat dalam hadis-hadis hisab rukyat dinilai bersifat ta'aqquli $m a^{\prime} q u l$ al-ma'na yang mana dapat dirasionalkan dan dikembangkan (Izzudin, 2007).

Hal ini jelas menujukkan perbedaan tafsir yang mempengerauhi metode penentuan awal bulan kamariah. Penentuan awal Bulan cukup dengan melakukan hisab, bahwa dalam hadis di atas disebutkan faqdurûlah wa lam yaqul tsalatsin (maka kira-kirakanlah tanpa menyebut 30 hari). Kata faqdurulah (kira-kirakan) dalam hadits di atas, di samping pemahaman tentang keumuman nash-nash dalam Al-Qur'an menunjukkan isyarat bahwa metode penghitungan dengan hisab juga 
merupakan suatu metode yang sah. Metode penentuan awal bulan tidak mengennal hierarki yang mengunggulkan salah satu dan menganggap keliru yang lainnya.

Dasar tentang berpegang kepada hisab untuk memahami nashnash (wajh alistidlal) tersebut yaitu keterangan dalam surat al-Rahman ayat 5 :

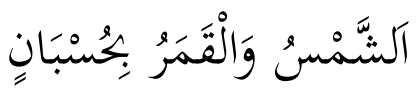

Artinya: "Matahari dan Bulan (beredar) menurut perhitungan".

Surat Yunus ayat 5 :

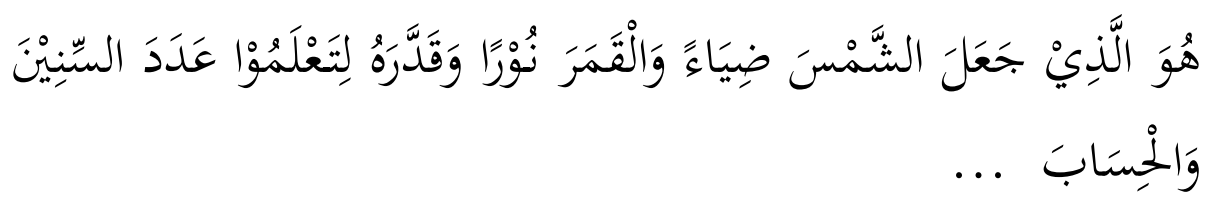

Artinya : "Dialah yang menjadikan matahari bersinar dan bulan bercahaya dan ditetapkan-Nya manzilah-manzilah (tempattempat) bagi perjalanan bulan itu, supaya kamu mengetahui bilangan tahun dan perhitungan (waktu) .....".

Dalil di atas menunjukkan fenomena astronomi yakni keberadaan benda-benda angkasa termasuk juga matahari dan bulan yang beredar sesuai orbitnya. Dengan demikian maka beredanya matahari dan bulan dapat diprediksi berdasarkan penghitungan seacara akurat. Informasi yang bersumber dari kedua surat tersebut yakni Rahman ayat 5 dan surat Yunus ayat 5 menunjukkan bahwa terdapat pernyataan imperatif yang dapat dimaknai bahwa ada perintah untuk manusia supaya mempelajari gerak dan peredaran benda-benda angkasa yang dapat membawa banyak kegunaan, seperti untuk menghayati keagungan tuhan, atau untuk kegunaan praktis bagi manusia itu sendiri, antara lain untuk dapat menyusun suatu sistem perubahan waktu yang baik (Anwar, 2008: 10). Di Indonesia, penetapan Awal bulan menggunakan hisab dalam menentukan awal bulan kamariah salah satunya digunakan oleh organisasi Muhammadiah.

Dalam sejarah peradaban Islam paradigma penentuan awal bulan dimulai sejak periode Rasulullah SAW kemudian dilanjutkan oleh para sahabat bahkan terus digunakan sampai sekarang ini, mulai dari masa pemahaman konsep geosentris sampai masa heliosentris. Artinya ada paradigma bahwa pada awalnya dikehendaki bahwa penentuan awal bulan Kamariah didasari pada terlihatnya bulan muda. 
Metode rukyat maupun hisab sebenarnya merupakan cara yang dilakukan untuk mengetahui masa waktu secara presisi dan akurat. Kedua metode tersebut juga dilakukan dengan kesungguhan dan niat ibadah. Di Indonesia upaya penyeragaman dalam menetapkan awal bulan Kamariah ini sudah sering dilakukan, bahkan salah satu tujuan utama berdirinya lembaga Badan Hisab dan Rukyat di Kementerian Agama pada tahun 1974, adalah dalam rangka upaya menyatukan penetapan awal bulan agar seragam. Namun, sampai sekarang upaya penyatuan penetapan awal bulan Kamariah, masih belum dapat terwujudkan, karena adanya sistem penetapannya masih beragam, dan belum adanya titik temu. Penulis menyajikan perbedaan hasil penentuan awal bulan diantara Muhammadiyah, NU, dan Pemerintah sebagai berikut:

Tabel.1

\begin{tabular}{|c|c|c|c|c|}
\hline No & Tahun & Muhammadiyyah & $\mathrm{NU}$ & Pemerintah \\
\hline 1 & 1985 & $\begin{array}{c}\text { Kamis, } 20 \text { Juni } \\
1985\end{array}$ & $\begin{array}{c}\text { Rabu, } 19 \text { Juni } \\
1985\end{array}$ & $\begin{array}{c}\text { Kamis, } 20 \text { Juni } \\
1985\end{array}$ \\
\hline 2 & 1992 & $\begin{array}{c}\text { Ahad, } 5 \text { April } \\
1992\end{array}$ & $\begin{array}{c}\text { Sabtu, } 4 \text { April } \\
1992\end{array}$ & $\begin{array}{c}\text { Ahad, } 5 \text { April } \\
1992\end{array}$ \\
\hline 3 & 1993 & $\begin{array}{c}\text { Kamis, } 25 \text { Maret } \\
1993\end{array}$ & $\begin{array}{c}\text { Rabu, } 24 \text { Maret } \\
1993\end{array}$ & $\begin{array}{c}\text { Kamis, } 25 \text { Maret } \\
1993\end{array}$ \\
\hline 4 & 1994 & $\begin{array}{c}\text { Kamis, } 25 \text { Maret } \\
1993\end{array}$ & $\begin{array}{c}\text { Ahad, } 13 \text { Maret } \\
1994\end{array}$ & $\begin{array}{c}\text { Senin, } 14 \text { Maret } \\
1994\end{array}$ \\
\hline 5 & 1998 & $\begin{array}{c}\text { Kamis, 29 Januari } \\
1998\end{array}$ & $\begin{array}{c}\text { Jum'at, } 30 \\
\text { Januari } 1998\end{array}$ & $\begin{array}{c}\text { Jum'at, } 30 \\
\text { Januari } 1998\end{array}$ \\
\hline 6 & 2006 & $\begin{array}{c}\text { Senin, } 23 \text { Oktober } \\
2006\end{array}$ & $\begin{array}{c}\text { Selasa, } 24 \\
\text { Oktober } 2006\end{array}$ & $\begin{array}{c}\text { Selasa, } 24 \\
\text { Oktober } 2006\end{array}$ \\
\hline
\end{tabular}

\section{Iddah Perspektif Fikih}

Pengertian "iddah" dapat dipahami secara bahasa maupun istilah. iddah secara bahasa berasal dari kata 'adda-ya'uddu-'idatan, jamaknya ialah "idad" yang secara arti kata berarti menghitung. Kata ini dimaksudkan untuk iddah karena dalam masa itu wanita yang beriddah menunggu berlalunya waktu (Syarifuddin, 2014: 303). Sedangkan dalam pengertian fiqih iddah berarti masa yang atur bagi wanita untuk menunggu 
berlalunya masa tunggu dari mantan suami setelah adanya perpisahan (Hamid, 2003:346).

Pada masa sebelum masuk peradaban Islam (masa jahiliyah) perempuan yang ditinnggal oleh suaminya sering tidak jujur terkait keaddaan dirinya yang tengah dalam kondisi hamil. Kondisi ini dimaksudkan supaya perempuan bisa segera menikah lagi. Namun, tak lama kemudian perempuan melahirkan anak. Kondisi ini dapat memicu perselisihan. Apabila mantan suami tidak mengakui bahwa itu anaknya, maka berdampak buruk bagi keberlangsungan hidup bayi yang tidak besalah itu disebabkan ibunya tidak jujur ketika masih dalam "iddah. Kasus lain muncul ketika isteri tidak mau berterus terang bahwa "iddahnya sudah habis, dia mengatakan masih dalam haid. Maksud kebohongan tersebut disampaikan supaya suaminya tetap memberi nafkah kepadanya selama ia tetap dalam iddah. Fenomena tersebut kemudian diperbaiki dengan tuntunan Islam seiring turunnya ayat 228232 surat Al-Baqarah yang melarang isteri yang dicerai menyembunyikan apa yang terjadi dalam rahimnya (Kusmidi, 2018: 38).

Masa iddah bisa menjadi kesempatan untuk membangun kembali hubungan karena sebelumnya pernah terjadi talak. Cukuplah waktu iddah itu bagi suami untuk menentukan sikap apakah ia akan rujuk kembali (lebih-lebih sudah ada anak) atau akan bercerai. Pada iddah ini suami boleh rujuk dengan maksud kembali membina rumah tangga yang lebih baik lagi. Jangan sampai upaya rujuk didasari maksud terselubung untuk membalas dendam dengan menyusahkan dan menyakiti isteri, maka perbuatan seperti itu dilarang Allah Swt dan itu perbuatan zalim terhadap perempuan (Kusmidi, 2018:38).

Dalam iddah talak raj'i dengan kesempatan masih boleh dirujuk merupakan uapaya mendorong kedua belah pihak yang bercerai untuk kembali memperbaiki hubungannya kembali. Iddah adalah upaya untuk saling introspeksi diri dan memutuskan untuk bersatu kembali atau tetap berpisah. Kewajiban suami untuk memberikan mut'ah bagi istri yang dicerai selama dalam masa iddah dan kewajiban istri untuk tetap tinggal serumah dengan suami secara jelas dimaksudkan agar kedua belah pihak dapat bersatu kembali (Wahyudi, 2016: 26). Jika perpisahan terjadi bukan karena perceraian tetapi karena kematian maka iddah dimaksudkan untuk menunjukkan rasa duka atas kematian suami. Rasa duka ini dimaksudkan untuk menjaga perasaan dari keluarga besar suami yang meninggal sehingga tidak menimbulkan persangkaan yang buruk.

1. Macam-macam iddah

Ada tiga macam iddah, yaitu iddah dengan tiga kali suci, iddah dengan hitungan bulan, dan iddah dengan lahirnya anak dari kandungan ibu (Hawwas, 2011: 322). 
a. Iddah dengan tiga kali masa suci

Ketentuan iddah dengan tiga kali masa suci ini berlaku jika wanita yang beriddah disebabkan karena berkahirnya perkawinan karena terjadinya perceraian, sedangkan wanita tersebut masih mengalami haid serta telah melakukan hubungan suami isteri (Basha, 2006: 751). Sebagaimana firman Allah dalam Surat alBaqarah Ayat 228 yang berbunyi:

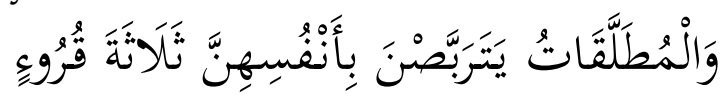

Artinya: "Wanita-wanita yang ditalak handaklah menahan diri (menunggu) tiga kali quru'".

Dari dalil di atas terdapat perbedaan penafsiran mengenai kata quru'. Menurut Imam Syafi'i dan Imam Maliki lafat quru' tersebut berarti suci. Dengan demikian iddah wanita tercerai adalah tiga kali suci. sedangkan menurut Imam Abu Hanifah dan Imam Ahmad bin Hambal lafadz quru' adalah berarti haid. Perbedaan tersebut dapat berdampak pada terjadinya perbedaan kehalalan suami untuk meruju' dan membina rumah tangga lagi dengan mantan istri, sebab perbedaan penafsiran dapat memanjang-pendekkan masa iddah. Dengan adanya ketentuan masa iddah tiga kali quru', masa ini cukup lama memberikan peluang yang dapat dimanfaatkan dengan baik bagi pihak laki-laki dan perempuan untuk intropeksi diri dan mengkaji kesalahan-kesalahan masa lalu yang telah diperbuat. Pada akhir keputusan untuk kembali rujuk dan tidak akan ada perpisahan lagi, bertekad untuk menjadikan rumah tangga yang lebih baik dari sebelumnya (Nurhayati, 2019:46).

b. Iddah dengan menghitung waktu beberapa bulan

Terdapat kondisi yang dapat diberlakukan masa iddah dengan beberapa bulan yakni: pertama, keadaan perempuan yang tidak mengalami haid sejak berpisah dengan suaminya. Hal ini berlaku bagi perempuan yang tidak haid karena belum masuk usia baligh, pengaruh internal dalam diri yang menyebabkan terputusnya siklus haidnya, maupun perempuan yang sama sekali tidak mengalami haid, dan telah melakukan hubungan suami isteri dengan suaminya. Maka iddah mereka adalah selama tiga bulan (Sabiq, 2011:220). Sebagaimana firman Allah dalam Surat at-Talaq ayat 4 yang berbunyi:

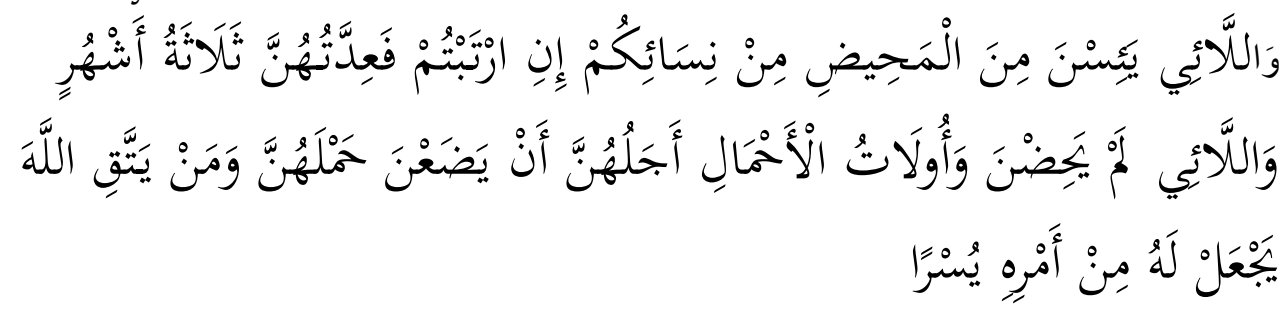


Artinya: "Dan perempuan-perempuan yang tidak haid lagi (monopause) di antara perempuan-perempuanmu jika kamu ragu-ragu (tentang masa iddahnya), Maka masa "iddahmereka adalah tiga bulan; dan begitu (pula) perempuan-perempuan yang tidak haid. dan perempuanperempuan yang hamil, waktu iddah mereka itu ialah sampai mereka melahirkan kandungannya. dan barang siapa yang bertaqwa kepada Allah, niscaya Allah menjadikan baginya kemudahan dalam urusannya".

Kedua, perempuan yang berpisah karena suaminya meninggal dunia. Masa "“iddahnya berlangsung selama empat bulan sepuluh hari. Kondisi ini berlaku baik setelah melakukan hubungan suami isteri maupun belum. Seperti dalam keterangan Firman Allah dalam surat al-Baqarah ayat 234 yang berbunyi:
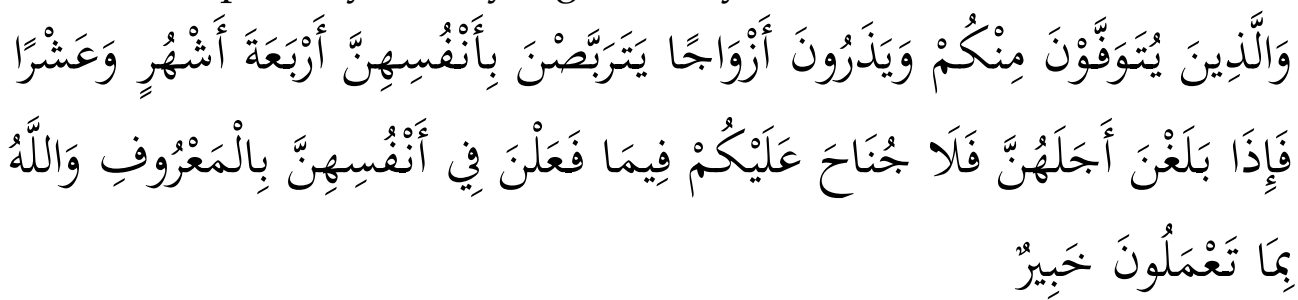

Artinya: "Orang-orang yang mati di antara kamu serta meninggalkan isteriisteri hendaklah mereka (isteri-isteri) menunggu empat bulan sepuluh hari. kemudian apabila telah sampai (akhir) "iddahmereka, maka tidak ada dosa bagimu mengenai apa yang mereka lakukan terhadap diri mereka menurut cara yang patut. Dan Allah maha mengetahui apa yang kamu kerjakan".

Masa iddah selama empat bulan sepuluh hari itu dapat dijadikann sebagai masa berkabung karena sedang dilanda duka. Walaupun dalam beberapa situasi orang tertentu dapat merasakan duka dalam waktu yang lebih singkat atau lebih lama. Disisi lain masa tunggu ini dapat dijadikan sebagai masa peralihan untuk mengatur dan merencanaka langkah selanjutnnya termasuk menikah lagi demi masa depannya. Begitu juga terhadap kehidupan anakanak yang ditinggalkan oleh bapaknya meninggal dunia, juga memerlukan perlindungan, pengayoman, pendidikan ataupun juga bantuan yang mungkin dapat diperoleh dari suami ibunya yang baru.(Amir, 2018:18).

c. Iddah dengan kelahiran kandungan

Pada bagian ini para Fuqaha' ketika wanita hamil lalu berpisah dengan suaminya, baik sebab talak, khulu', maupun fasakh iddahnya ialah sampai melahirkan kandungan. 


\section{Hak dan Kewajiban Perempuan Iddah}

1. Hak Istri selama dalam Masa iddah

Setiap perempuan yang sedang dalam masa iddah, Baik karena ditinggal wafat suami atau sebab ditalak memiliki suatuh hak yang harus dipenuhi. Selain adanya hak maka didalamnya terdapat suatu hikmat yang dapat diperoleh.

a. Hak istri setelah ditalak

Seorang suami ketika berpisah dan berstatus mantan suami tetap memiliki tanggung jawab yang harus dipenuhi. Seorang perempuan yang berpisah karena perceraian dan harus meewati masa iddah maka mendapat suatu hak dari mantan suami walaupun hak tersebut tentu berbeda seperti saat berstatus suami istri. Bentuk hak yang diterima perempuan juga tergantung kepada bentuk perceraiannya (Syarifuddin, 2014: 322). Dalam hal terjadi perceraian talaq kewajiban memberikan nafkah tetap melekat pada tanggung jawab mantan suami. Dengan demikian dapat dipahami bahwa suami istri hanya terlepas dari hubungan seksualnya saja.

Adapun hak yang wajib diberikan seorang suami kepada istri yang telah ditalak adalah nafkah. Para ahli Fikih telah sepakat, bahwa perempuan yang iddah talak raj'i berhak mendapat nafkah berupa belanja pangan, pakaian dan tempat tinggal dari suami yang menceraikannya. Dan bagi suami diperbolehkan untuk ruju' asalkan masa iddahnya belum berakhir. Perempuan yang ditalak suaminya baik raj'i maupun ba'in dan dalam keadaan hamil maka ia juga berhak untuk mendapatkan nafkah tersebut sampai yang bersangkutan melahirkan. Allah SWT. Berfirman dalam surat AtTalaq ayat 4 yang berbunyi:

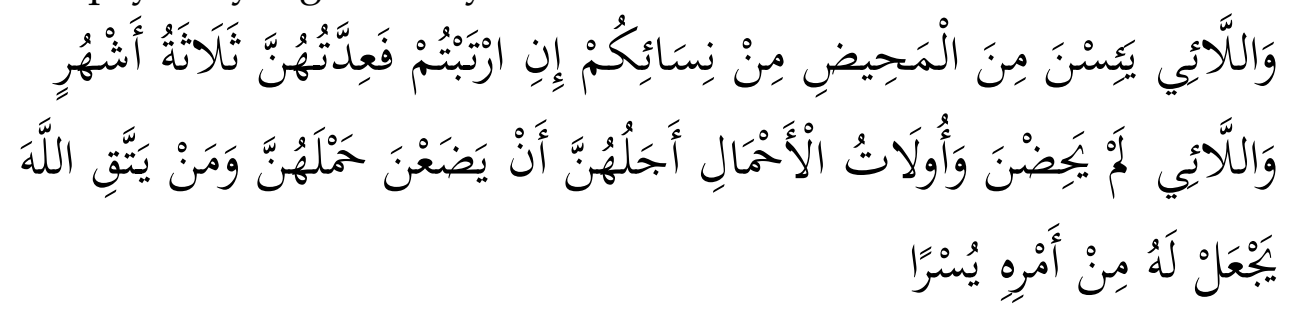

Artinya: "Dan perempuan-perempuan yang tidak haid lagi (monopause) di antara perempuan-perempuanmu jika kamu ragu-ragu (tentang masa “"iddahnya), Maka masa "iddahmereka adalah tiga bulan; dan begitu (pula) perempuan-perempuan yang tidak haid. dan perempuan-perempuan yang hamil, waktu "iddahmereka itu ialah sampai mereka melahirkan kandungannya. dan barang -siapa yang bertakwa kepada Allah, niscaya Allah menjadikan baginya kemudahan dalam urusannya". 
Kewajiban memberikan nafkah bagi perempuan yang dicerai dengan talak ba in, baik ba'in sughra maupun kubra sedang tidak dalam keadaan hamil, menurut Imam Syafi'i bahwa Istri tersebut hanya dapat tempat tinggal tidak nafkah (Al-Hishni, n.d.). Dengan demikian menujukkan bahwa setelah perceraian bagi kedua belah pihak yang telah bercerai, masing-masing tetap mempunyai hak dan kewajiban. Suami harus memberikan penghidupan yang layak pada mantan istri. istri tidak mendapatkan hak-hak yang diatur dalam Kompilasi Hukum Islam, maka ia dapat mengajukan tuntutan kepada mantan suaminya ke pengadilan agama di tempat melangsungkan perceraian.

b. Hak istri setelah suami meninggal

Seorang perempuan yang ditinggal wafat suaminya dan tidak dalam keadaan hamil maka ia tidak berhak mendapatkan nafkah dan tempat tinggal. Apabila perempuan tersebut itu hamil maka juga tidak berhak mendapatkan nafkah juga tempat tinggal. Namun menurut madzhab Imam Maliki perempuan tersebut hanya berhak tempat tinggal (Al-Jaziri, 2003: 504). Menurut kesepakatan ulama Fiqih, bagi perempuan yang beriddah wafat karena talak raj'i, maka perempuan tersebut berhak menerima harta warisan. Sedangkan perempuan yang menjalani iddah wafat karena talak bain maka ia tidak berhak mendapat harta warisan dari suaminya yang wafat. Hal ini telah dijelaskan dalam firman Allah SWT surat Al-Baqarah ayat 228 (Dahlan, 1996: 641).

2. Kewajiban Istri selama dalam masa iddah

Dalam Hukum Islam, ada beberapa kewajiban bagi perempuan yang melaksanakan iddah. Di antaranya adalah:

a. Haram menerima pinangan

Khitbah atau peminangan secara etimologi adalah permintaan. Sedangkan menurut terminologi adalah permintaan seorang laki-laki untuk menguasai seorang wanita tertentu dari keluarganya dan bersekutu dalam urusan kebersamaan hidup. Atau dapat juga diartikan, seorang laki-laki menampakkan kecintaannya untuk menikahi seorang wanita yang halal dinikahi secara syara'. Peminangan dapat dilakukan secara langsung oleh peminang kepada yang dipinang, atau dengan melalui keluarga, dan atau melalui utusan seseorang yang dapat dipercaya untuk meminta orang yang dikehendaki (terpinang) (Mukhtar, 1993: 28).

Khitbah merupakan pendahuluan dalam perkawinan yang disyariatkan sebelum ada ikatan suazmi istri. Hal ini dimaksudkan agar waktu memasuki perkawinan didasarkan kepada penelitian dan pengetahuan serta kesadaran masing-masing pihak (Idhomy, n.d.). Perempuan yang sedang menjalani iddah tidak boleh 
menerima pinangan lamaran dari laki-laki, baik secara sindiran (ta'ridl) maupun secara jelas (tashrih). Akan tetapi, bagi perempuan yang menjalani masa iddah kematian suaminya, maka pinangan tersebut boleh dilakukan namun dengan cara sindiran. Dasar penetapan hukum ini adalah firman Allah yang terdapat dalam Surat al-Baqarah ayat 235 yang berbunyi:

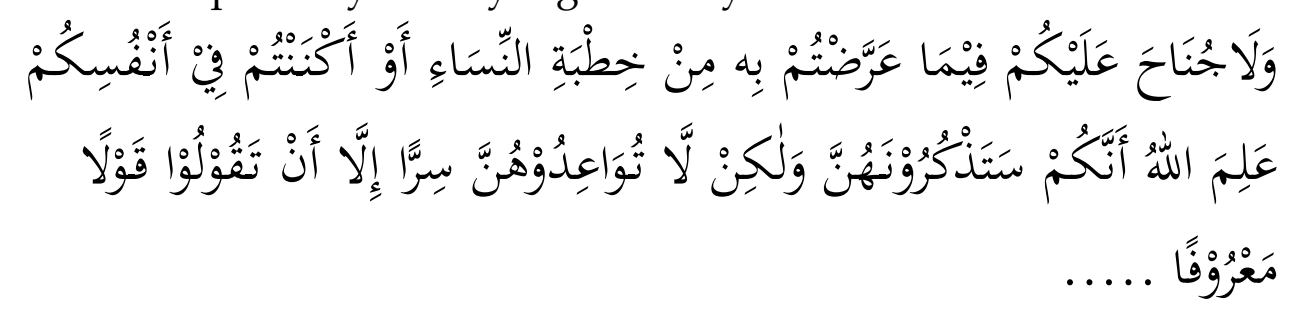

Artinya : "Dan tidak ada dosa bagi kamu meminang "perempuanperempuan itu" dengan sindiran atau kamu menyembunyikan (keinginan mengawini mereka) dalam hatimu. Allah mengetahui bahwa kamu akan menyebutnyebut mereka, dalam pada itu janganlah kamu mengadakan janji kawin dengan mereka secara rahasia, kecuali sekadar mengucapkan (kepada mereka) perkataan yang ma'ruf....".

Maksud dari "perempuan-perempuan itu" adalah perempuan yang telah ditinggal wafat oleh suaminya. Lebih dari itu, perempuan yang menjalani masa iddah tidak boleh melaksanakan akad perkawinan, baik kawin atau dikawini secara mutlak. Hal ini berdasarkan pada lanjutan Surah al-Baqarah ayat 235 di atas, yaitu:

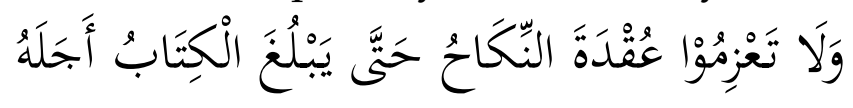

Artinya: “...Dan janganlah kamu ber'azam (berketetapan hati) untuk berakad nikah, sebelum habis " iddahnya..."

Hal ini tidak diperbolehkan karena dengan menampakkan rasa senangnya kepada perempuan tersebut bisa menjadikan sang perempuan berbohong akan masa "iddahnya. Umpamanya, semestinya seorang perempuan baru akan berakhir masa "iddahnya dua bulan yang akan datang, namun karena saat ini ada laki-laki yang mau menikahinya maka ia berbohong dengan mempercepat masa iddahnya agar bisa segera menikah dengan laki-laki tersebut sehingga tak lagi menyandang status janda.

b. Dilarang keluar rumah

Perempuan mu'taddah talak raj'i tidak diperbolehkan keluar rumah, baik ketika siang maupun malam, karena segala keperluan dipenuhi oleh suami yang mentalaknya. Keluar rumah ketika siang hari hanya diperbolehkan bagi perempuan yang ditalak ba in. Alasan mereka adalah keterangan yang terdapat dalam sebuah hadits dari 
Jabir bin Abdullah; "Jabir berkata: Bibi dari ibuku ditalak tiga oleh suaminya lalu ia keluar untuk memotong kurmanya. Tiba-tiba ia ditemui oleh seorang laki-laki, kemudian melarangnya keluar. Maka saya menceritakan hal tersebut kepada Rasulullah SAW. Kemudian Nabi SAW bersabda, pergilah engkau ke kebunmu itu untuk memetik buah kurma, semoga engkau bersedekah dengan buah kurma itu dan lakukanlah yang baik menurutmu." (HR. al-Nasa'i dan Abu Dawud).

c. Wajib untuk melaksanakan ihdad.

Secara etimologis, ihdad berarti mencegah dari memakai perhiasan. Dalam kamus bahasa Arab, ihdad berarti keadaan seorang perempuan yang tidak bersolek atau menghias dirinya sebagai tanda rasa berkabung atas meninggalnya suaminya atau keluarganya(Qudamah, 1980:291). Namun rasa berkabung atas selain suami, ihdad hanya dilakukan sampai tiga hari. Dalam keterangan fikih konvensional, ihdad berlaku khusus bagi perempuan yang ditinggal mati suaminya, dan tidak berlaku sebaliknya, atau berlaku terhadap suami yang ditinggal mati istrinya. Ihdad juga tidak dikenakan kepada istri yang ditalak raj'i dan talak ba 'in(Al-Syairaziy, n.d.). Ihdad dalam keterangan kitab-kitab kuning, selalu dinyatakan wajib hukumnya bagi istri yang suaminya wafat untuk melakukannya dengan tujuan menyempurnakan penghormatan kepada suami dan untuk memelihara haknya (Al-Namiriy, 1992: 294).

Dalil tentang disyari'atkannya ihdad adalah firman Allah SWT yang terdapat dalam Surat al-Talaq ayat 1 yang berbunyi:

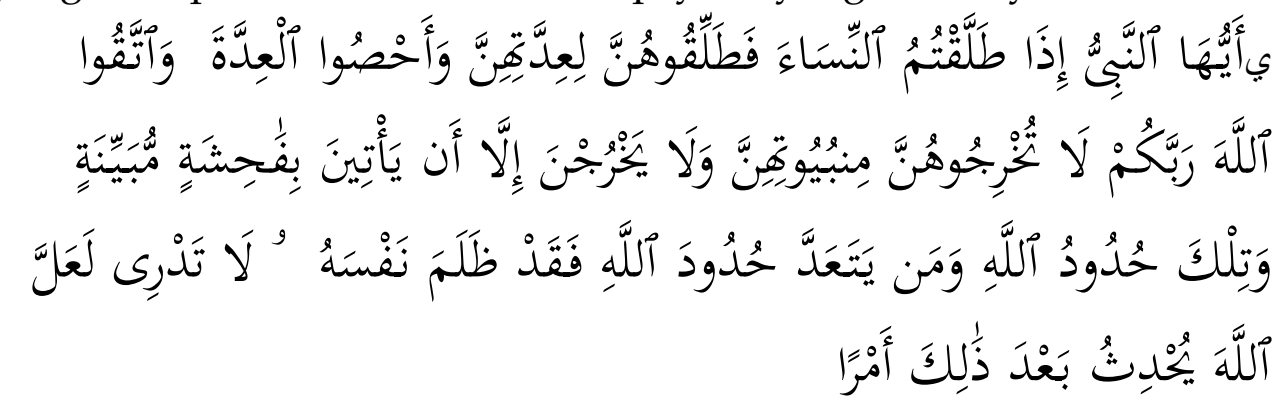

Artinya: "Hai Nabi, apabila kamu menceraikan istri-istrimu, maka hendaklah kamu ceraikan mereka dapat (menghadapi) iddah-nya (yang wajar) dan hitunglah waktu "iddahitu serta bertakwalah kepada Allah, Tuhanmu. Janganlah kamu keluarkan mereka dari rumah mereka dan janganlah mereka (diizinkan) ke luar kecuali kalau mereka mengerjakan perbuatan keji yang terang". 
Berdasarkan dalam suatu Hadits bahwa Rasulullah SAW bersabda :

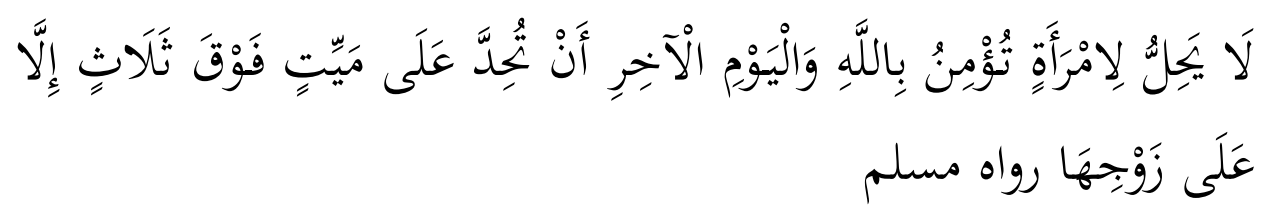

Artinya : "Tidak boleh seorang wanita yang beriman kepada Allah dan hari Akhir untuk tidak berkabung atas kematian melebihi tiga hari, kecuali atas kematian suaminya" (HR. Muslim) (Hazm, n.d.).

Kemudian dalam hadis riwayat Ummi Salamah, Rasul SAW bersabda: "Terhadap perempuan yang ditinggal mati suaminya, janganlah ia memakai pakaian yang dicelup, jangan memakai perhiasan, jangan memakai pewarna wajah, dan jangan bercelak" (HR. Ahmad ibn Hanbal, Abu Dawud, dan al-Nasa i). Selain itu Hadits yang telah diriwayatkan oleh Imam al-Bukhari dan Imam Muslim juga berasal dari riwayat Ummu 'Athiyah yang juga berisi tentang larangan yang sama tersebut. Dinyatakan bahwa bila ada seorang istri yang ditinggal mati suaminya dan mengetahui bahwa ihdad itu wajib hukumnya untuk dilakukan selama masa iddah, akan tetapi ia tidak melakukannya, maka ia termasuk telah mendurhakai Allah.

Keterangan dalam Kitab Fikih Konvensional, bahwa perempuan yang ditinggal wafat oleh suami atau keluarganya harus melakukan ihdad dengan menjauhi hal-hal berikut:

1) Memakai perhiasan cincin emas atau perak. Pelarangan ini diakui oleh ahli Fikih pada umumnya, kecuali menurut sebagian madzhab as-Syafi'i;

2) Memakai pakaian yang berbau wangi;

3) Memakai pakaian yang bahannya terbuat dari sutera berwarna putih;

4) Memakai pakaian yang dicelupkan dengan warna yang mencolok, seperti warna kuning atau merah. Menurut ahli fikih, umumnya perempuan tersebut diperbolehkan memakai pakaian yang berwarna hitam. Namun, menurut pendapat madzhab maliki, menggunakan pakaian yang berwarna hitam juga tidak boleh dipakai, kecuali bila dalam kalangan masyarakat perempuan tersebut, warna hitam dipandang untuk mempercantik diri;

5) Memakai wewangian atau parfum pada tubuhnya, kecuali bila untuk keperluan menghilangkan bau yang tidak sedap pada kemaluannya sehabis haidl. Bahkan, menurut madzhab maliki, bahwa perempuan yang sedang menjalankan ihdad tidak boleh melakukan pekerjaan yang masih ada kaitannya dengan 
wewangian, seperti menjadi seorang pembuat atau pedagang minyak wangi;

6) Membalur minyak pada rambut, baik minyak tersebut beraroma wangi maupun tidak;

7) Memakai celak, karena hal tersebut dapat memperindah mata. Menurut ulama fikih, jika bercelak dengan niat untuk keperluan pengobatan maka hukumnya boleh dilakukan waktu malam hari, sedangkan jika dilakukan pada siang hari, maka tetap tidak dibenarkan;

8) Mewarnai kuku dengan pacar kuku dan semua hal-hal yang berkaitan dengan pewarnaan pada wajah. Larangan-larangan tersebut berdasarkan hadits riwayat imam bukhari dan imam muslim dan hadis Imam Al-Nasa i dan Imam Ahmad Ibn Hanbal (Al-Zuhailiy, N.D.).

Selain itu, larangan lain dalam berihdad adalah larangan untuk keluar rumah, kecuali bila untuk memenuhi kebutuhan yang pokok, misalnya untuk mencari nafkah. Ketegasan penisaban keturunan dalam Islam merupakan hal yang amat penting. Oleh karena itu, segala ketentuan untuk menghindari terjadinya kekacauan nisab keturunan manusia ditetapkan di dalam Al-Qur'an dan Sunnah dengan tegas. Diantara ketentuan tersebut adalah larangan bagi wanita untuk menikah dengan beberapa pria dalam waktu yang bersamaan. Dan di samping itu untuk menghilangkan keraguan tentang kesucian rahim wanita tersebut, sehingga pada nantinya tidak ada lagi keraguan tentang anak yang dikandung oleh wanita itu apabila ia telah menikah lagi dengan laki-laki lain.

Lebih jauh tujuan adanya iddah itu tidak hanya untuk mengetahui bersihnya rahim, akan tetapi dalam iddah juga mengandung unsur ta'abbudi. Dengan kata lain, iddah mengandung dua hal, yaitu yang bersifat $t a^{\prime} a q q u l i$ dan $t a^{\prime} a b b u d i$. Yang dimaksud dengan ta'aqquli adalah hal-hal yang bersifat rasional atau dapat dinalar. Dalam konteks iddah maka unsur ta"aqquli-nya antara lain adalah untuk mengetahui bersihnya rahim, di mana hal ini jelas-jelas bisa dinalar. Dengan kata lain, sesuatu itu bersifat ta'aqquli apabila diketahui kemaslahatannya melalui nalar sehat Sedang yang dimaksud ta'abbudi ini adalah hal yang tidak bisa dinalar. Dalam konteks iddah adalah menjalani masa iddah sampai selesai sesuai ketentuan yang telah ditetapkan, meskipun sudah dapat dipastikan bahwa rahimnya bersih. Karena itu maka para ulama mendefiniskan iddah sebagai masa tunggu bagi seorang perempuan untuk mengetahui bersihnya rahmi atau rahim dari kehamilan atau untuk tujuan ta'abbudi. 
Berdasarkan penjelasan tersebut dapat dipahami bahwa perempuan yang cerai harus menjalani masa iddah, meskipun bersihnya rahim sudah dapat diketahui sebelum selesai masa iddahnya. Menurut penulis bahwa alasan yang dapat dikemukakan dalam konteks ini adalah bahwa iddah bukan semata-mata hal yang bersifat ta'aqquli seperti mengetahui bersihnya rahmi, tetapi juga bersifat ta'abbudi atau bernilai ibadah sehingga iddah harus dijalani sampai selesai pada waktu yang telah ditentukan.

\section{Implikasi Perbedaan Penentuan Awal Bulan Kamariah dalam Penghitungan Masa Iddah Bagi Perempuan}

Seperti yang terjadi pada penetapan awal bulan Syawal pada tahun 2006 (lihat tabel 1), pada tahun tersebut menurut Muhammadiyyah, untuk tanggal 1 Syawal 1427 jatuh pada hari Senin, 23 Oktober 2006, sedangkan menurut NU, untuk 1 Syawwal 1427 jatuh pada hari Selasa, 24 Oktober 2006 dengan jumlah hari pada bulan Romadlan digenapkan menjadi 30 hari. Hal ini berarti terpaut satu hari dalam penetapannya. Secara sepintas, perselisihan jumlah hari hanya terpaut satu hari, tidak ada pengaruhnya. Padahal sesungguhnya perbedaan penentuan memberikan dampak hukum yang sangat signifikan (Izzudin, 200: 37).

Kemudian apabila seseorang perempuan yang sedang beriddah tiga bulan, yang dimulai pada tanggal satu Rajab, dan iddahnya berakhir pada akhir Ramadlan, jika kejadian tersebut terjadi pada akhir Romadlon tahun $1427 \mathrm{H}$, Maka hal ini tidak hanya berakibat terdapat perbedaan jumlah anatara madzhab rukyat dengan madzhab hisab, namun juga berakibat hukum yang menyangkut kehalalan dan keharaman suami istri, serta hakhak suami istri selama beriddah. Perempuan yang ditalak $r a j ' i$ atau dicerai satu dan dua, itu pernikahannya belum bisa dikatakan putus dalam maknya sesungguhnya, oleh karena itu, perempuan tersebut selama masa iddah tetap dipandang sebagai istri dari suaminya, dan begitu sebaliknya. Yang keduanya mempunyai hak dan kewajiban.

Diantara hak istri yang ditalak raj'i adalah nafkah pangan, pakaian, dan tempat. Yang semuanya itu termasuk kewajiban suami. Bila perempuan tersebut mengacu pada kelompok yang menggunakan metode hisab, maka pada hari Selasa 23 September 2006, perempuan tersebut sudah tidak mendapatkan nafkah wajib dari suaminya. Bila mengikuti kelompok yang menggunakan metode rukyat, pada hari tersebut perempuan masih mendapatkan nafkah. Kemudian ada juga hak suami yang dapat dilakukan olehnya pada masa iddah talak raj'i, yaitu ruju' kembali kepada istrinya. Hal ini menandakan perbedaan penentuan awal bulan juga berpengaruh pada sang suami, Jika suami tersebut mengikuti kelompok yang menggunakan metode hisab, tentunya keinginan untuk ruju' jangan sampai melewati hari selasa, 23 September 
2006. Namun bila mengikuti kelompok yang menggunakan metode rukyat, tanggal 23 September 2006 masih bisa ruju'.

Menurut penulis permasalahan penentuan di atas tidak hanya berakibat hukum masih boleh atau tidaknya ruju' kepada istrinya, tetapi juga berkonsekuensi masih saling mewarisi, diantara suami atau istri yang menjalani iddah raj'i. Dalam ketentuan Fikih, apabila suami meninggal, maka istri yang sedang iddah talak raj'i, berhak menjadi ahli waris suaminya sebelum iddahnya berakhir. Hal ini sebaliknya, suami masih menjadi ahli waris istrinya yang meninggal selama iddah belum berakhir. Ketika mengacu pada hitungan kelompok yang menggunakan metode hisab, ketika suami meninggal pada tanggal 23 September 2006, maka sang istri tidak dapat mewaris. begitu juga sebaliknya. Namun, bila mengaikuti pada kelompok yang menggunakan metode rukyat, ketika suami meninggal tanggal 23 September 2006, maka istri masih dapat mewaris.

Kriteria yang kedua, adalah “iddahnya seorang istri yang ditinggal wafat suaminya yaitu selama empat bulan sepuluh hari. Seperti halnya iddahnya seorang perempuan yang ditalak raj'i, seorang perempuan yang ditinggal wafat suaminya juga mendapat akibat hukum akan adanya pengaruh perbedaan awal bulan.

Apabila awal iddah seorang yang ditinggal wafat suaminya dimulai pada tanggal satu Jumadil Akhir, maka jika dihitung empat bulan sepuluh hari, berarti iddahnya sampai tanggal sepuluh syawal, padahal tanggal sepuluh syawal bagi hitungan kelompok yang menggunakan metode hisab dan kelompok yang menggunakan metode rukyat terpaut satu hari, dikarenakan tanggal satu Syawal menurut kelompok yang menggunakan metode hisab itu adalah tanggal 23 September 2006, sedangkan kelompok yang menggunakan metode rukyat tanggal 24 September 2006, yang artinya tanggal sepuluh Syawal menurut kelompok yang menggunakan metode hisab jatuh pada 2 Oktober 2006, dan menurut kelompok yang menggunakan metode rukyat jatuh pada tanggal 3 Oktober 2006. Jika perempuan yang ditinggal wafat suaminya mengikuti pendapat madzhab hisab, pada tanggal 3 Oktober 2006 "iddah perempuan tersebut sudah selesai, bila mengikuti madzhab rukyat, pada tanggal tersebut masih berlum selesai.

Kemudian terkait kewajiban bagi seorang perempuan yang ber iddah talak raj'i dan iddah ditinggal wafat suaminya yaitu salah satunya adalah larangan menerima pinangan, dan menikah. Larangan ini tidak boleh dilakukan, baik bagi yang iddah talak raj'i atau iddah ditinggal wafat suaminya, kecuali jika masa iddahnya sudah berakhir. Namun bagi perempuan iddah ditinggal wafat, boleh dipinang dengan sindiran. Adapun melakukan pernikahan bagi keduanya hukumnya tetap tidak diperbolehkan. Perbedaan penetuan awal bulan juga berpengaruh pada 
kedua perempuan tersebut. Bila mengikuti pendapat kelompok yang menggunakan metode hisab, pada tanggal 1 Syawal 1427 versi kelompok yang menggunakan metode hisab yang bertepatan 23 September 2006, seorang perempuan yang beriddah raj'i sudah diperbolehkan dipinang dan dinikah oleh laki-laki lain, begitu juga sebaliknya, bila mengikuti kelompok yang menggunakan metode rukyat, pada tanggal 23 September 2006 masih belum diperbolehkan dipinang dan dinikah oleh laki-laki lain. Karena pada tangga tersebut, menurut kelompok yang menggunakan metode rukyat, iddahnya belum selesai.

Begitu halnya bagi perempuan yang beriddah karena ditinggal wafat suaminya, bila menurut kelompok yang menggunakan metode hisab, hitungan empat bulan sepuluh hari atau pada 10 Syawal 1427 jatuh pada hari Senin, 2 Oktober 2006, dengan artian hari berikutnya pada tanggal Selasa, 3 Oktober 2006 perempuan tersebut sudah selesai menjalakan iddah, konsekuensinya menurut ahli Fikih berarti diperbolehkan untuk dipinang atau dinikah. Akan tetapi bila mengikuti kelompok yang menggunakan metode rukyat, tanggal 3 Oktober 2006, iddah belum selesai. Tentunya masih belum diperbolehkan untuk dipinang atau dinikah, dan menunggu hari besoknya.

Senada dengan larangan melakukan pinangan dan pernikahan, yaitu larangan keluar rumah dan pelaksanaan ihdad, yang mana keduanya sama-sama tidak boleh dilakukan bagi orang yang beriddah wafat suaminya kecuali idahnya telah selesai. Adapun bagi perempuan yang ber iddah talak raj'i hanya dilarang untuk keluar rumah, dan untuk berihdad tidak diwajibkan.

Menurut kelompok yang menggunakan metode hisab pada tanggal 23 September 2006 perempuan yang melaksanakan iddah talak raj'i sudah diperbolehkan untuk keluar rumah tanpa harus ada alasan keperluan mendasar, misal untuk memnuhi kebutuhan sehari-hari, sebaliknya bila mengacu kelompok yang menggunakan metode rukyat pada tangal tersebut masih belum diperkenankan, dan menunggu hari besoknya. Begitu juga, pada tanggal 3 Oktober 2006 menurut kelompok yang menggunakan metode hisab perempuan yang beriddah ditinggal wafat suaminya juga sudah diperbolehkan keluar rumah dan sudah diperbolehkan memakai perhiasan, minyak parfum, dan semua larangan yang berkaian dengan ihdad yang tidak boleh dilakukan saat iddahnya belum selesai. Sebaliknya, bila mengikuti kelompok yang menggunakan metode rukyat, pada tanggal 3 Oktober 2006, perempuan tersebut masih belum diperbolehkan dan mulai diperbolehkan pada hari berikutnya, yaitu tanggal 4 Oktober 2006. 


\section{SIMPULAN}

Berdasarkan pembahasan di atas, dapat disimpulkan bahwa perbedaan dalam penentuan awal bulan kamariah terjadi dikarekan perbedaan metode yang digunakan dikalangan umat Islam yaitu antara rukyah dan hisab. Perbedaan metode tersebut juga berimplikasi terhadap penghitungan iddah bagi perempuan seperti perempuan yang beriddah 4 bulan 10 hari dan 3 bulan akan mendapatkan pengaruh terkait tentang hak dan kewajiban yang didapatnya. Hak yang didapatkan perempuan iddah antara lain nafkah pangan, pakaian, tempat, serta hak mendapatkan warisan. Adapun kewajiban perempuan yang beriddah adalah terkait menerima pinangan, menikah, keluar rumah, dan melaksanakan ihdad. Sedangkan dikalangan ulama Fikih, iddah cenderung diartikan sebagai masa tunggu bagi seorang perempuan untuk mengetahui bersihnya rahmi atau rahim dari kehamilan atau untuk tujuan $t a^{\prime} a b b u d i$.

\section{DAFTAR PUSTAKA}

\section{Buku-buku}

Al-Dzahabiy. (1968). al-Syarî'ah al-Islâmiyyah: Dirâsah Muqaranah baina Ahli al-Sunnah wa Madzhab a-Ja'fariyyah. Mesir: Dar al-Kutub al-Hadtsah.

Al-Hajjaj, A. H. M. bin. (n.d.). Al-Jami' as-Shahih Muslim (Jilid 3). Beirut: Dar al-Fikr.

Al-Hishni, A. B. (n.d.). Kifayah al-Akhyar fi Hall Ghayah al-Ikhtishar. Beirut: Dar al-Fikr.

Al-Jaziri, A. R. (2003). Kitab al-Fiqhi Al Madzahabi al-Arba'ah. Lebanon: Dar al-Kutub.

Al-Namiriy, A. 'al-B. (1992). al-Kafiy fiy Figh Ahl al-Madinah al-Malikiy. Beirut: Dar al-Kutub.

Anwar, S. (2008). Kontroversi Hisab dan Rukyat dalam Hisab Awal Bulan Kamariyah: Tinjauan Syar'i tentang Penetapan Awal Ramadhân, Syawwâl dan Dzulhijjah. Yogyakarta: Suara Muhammadiyah.

Basha, M. Q. (2006). al-Ahkam ash-Shar'iyah Fi al-Ahwal ash-Shakhsiyah. Kairo: Darus Salam.

Dahlan, A. A. (1996). Ensiklopedi Hukum Islam (cet. Ke-6). Jakarta: htiar Baru Van Hoeve.

Dirjen BIPH. (2004). Selayang Pandang Hisab Rukyat. Agama, Direktorat Jendral Bimas Islam dan Penyelenggaraan Haji Direktorat Pembinaan Peradilan Agama.

Hamid, M. M. A. (2003). Al-Ahwal ash-Shakhsiyah Fi Shari'ati al-Islamiyah. Beirut: al-Maktabah al-Alamiyah. 
Perbedaan Penentuan Awal Bulan Kamariah dalam...

Hawwas, A. A. M. A. dan A. W. S. (2011). Fikih Munakahat. Jakarta: Amzah.

Idhomy, D. (n.d.). Asas-asas Fikih Munakahat Hukum Keluarga Islam (cet ke1). Surabaya: al-Ikhlas.

Izzudin, A. (2007). Fiqih Hisab Rukyah: Menyatukan NU \& Muhammadiyah dalam Penentuan Awal Ramadhan, Idul Fitri, dan Idul Adha. Jakarta: Erlangga.

Mukhtar, K. (1993). Asas-asas Hukum Tentang Perkawinan (cet ke-2). Jakarta: Bulan Bintang.

Nasution, H. (1999). Ensiklopedi Islam. Jakarta: letar Van Hoeve.

Nurhayati. (2019). Iddah Dalam Perceraian. Warta Edisi 60, (April), 91-96.

Qudamah, I. (1980). al-Muqni' fiy Figh Imam al-Sunnah Ahamd ibn Hanbal alSyaibaniy. Riyadl: Maktabah al-Riyadl al-Haditsah.

Sabiq, S. (2011). Fikih as-Sunnah (Jilid II). Beirut: al-Maktabah al-'Asriyyah. Syarifuddin, A. (2014). Hukum perkawinan Islam di Indonesia; Antara Fikih Munakahat dan Undangundang Perkawinan. Jakarta: Kencana.

\section{Jurnal-jurnal}

Amir, R. R. (2018). Iddah (Tinjauan Fiqih Keluarga Muslim). Jurnal AlMau'izhah, 1(1), 13.

Arifin, O. J. (2014). Fiqih Hisab Rukyah Di Indonesia ( Telaah Sistem Penetapan Awal Bulan Qamariyyah ). Yudisia, Vol5,No2(Disember), 402-422.

Jamhuri, \& Juliara, I. (2017). Penggabungan iddah wanita hamil dan kematian suami (Analisis terhadap pendapat mazhab syafi'i). Samarah, 1(1), 226-247. https:/ / doi.org/10.22373/sjhk.v1i1.1581

Khitam, H. (2020). Nafkah dan Iddah: Perspektif Hukum Islam. 12(2), 189-205.

Kusmidi, H. (2018). Reaktualisasi Konsep Iddah Dalam Pernikahan. Jurnal Ilmiah Mizani: Wacana Hukum, Ekonomi Dan Keagamaan, 4(1), 33-42. https:/ / doi.org/10.29300/mzn.v4i1.1007

Wahyudi, M. I. (2016). Kajian Kritis Ketentuan Waktu Tunggu (“Iddah) Dalam Ruu Hmpa Bidang Perkawinan (The Critical Study of Waiting Period Regulation on The Bill of The Religious Courts Material Law Marriage Matters). Jurnal Hukum Dan Peradilan, 5(1), 19. https://doi.org/10.25216/jhp.5.1.2016.19-34 
Muhammad Alamul Huda

Halaman ini sengaja dikosongkan 